\title{
A redescription of Aculepeira matsudae (Aranei: Araneidae), a species recently found in Far East Russia
}

\section{Переописание паука-кругопряда Aculepeira matsudae (Aranei: Araneidae), недавно найденного на Аальнем Востоке России}

\author{
Yuri M. Marusik ${ }^{1-3}$, Mikhail M. Omelko ${ }^{4-5}$, Pavel S. Simonov ${ }^{6}$ \\ Ю.М. Марусик ${ }^{1-3}$, М.М. Омелыко ${ }^{4-5}$, П.С. Симонов
}

\footnotetext{
${ }^{1}$ Institute for Biological Problems of the North, FEB RAS, Portovaya Str. 18, Magadan, Russia. E-mail: yurmar@mail.ru

${ }^{2}$ Department of Zoology \& Entomology, University of the Free State, Bloemfontein 9300, South Africa

${ }^{3}$ Zoological Museum, Biodiversity Unit, University of Turku, FI-20014, Finland.

${ }^{4}$ Federal Scientific Center of East Asia Terrestrial Biodiversity, Far Eastern Branch, Russian Academy of Sciences, Vladivostok 690022, Russia. E-mail: omelkom@gmail.com

${ }^{5}$ Far Eastern Federal University, Sukhanova 8, Vladivostok RF-690950, Russia.

${ }^{6}$ Pacific Geographical Institute, Far Eastern Branch, Russian Academy of Sciences, Radio Str. 7, Vladivostok, 690041, Russia E-mail: palzpss@yandex.ru

${ }^{1}$ Институт биологических проблем Севера ДВО РАН, Портовая 18, Магадан 685000 Россия.

${ }^{4}$ Федеральный научный центр Биоразнообразия наземной биоты Восточной Азии ДВО РАН, Владивосток 690022, Россия.

5 Дальневосточный федеральный университет, улица Суханова 8, Владивосток 690950, Россия.

6 Федеральное государственное бюджетное учреждение науки, Тихоокеанский институт географии ДВО РАН, Владивосток 690041, ул. Радио 7, Россия.
}

KEY WORDS: Araneae, Far East Asia, Primorskii Krai, Khabarovskii Krai.

КЛЮЧЕВЫЕ СЛОВА: Araneae, Дальневосточная Азия, Приморский край, Хабаровский край.

ABSTRACT. Aculepeira matsudae Tanikawa, 1994, a species previously known from Central Hokkaido is reported from Far East Russia for the first time. Previously it was recorded in Khabarovsk and Maritime Provinces as Aculepeira cf. matsudae. The species is redescribed in detail, and an updated diagnosis is provided as well as comparisons with two other species occurring in Far East Russia. The status of species assigned to Aculepeira that occur in the Neotropical Realm is briefly discussed.

How to cite this article: Marusik Yu.M., Omelko M.M., Simonov P.S. 2020. A redescription of Aculepeira matsudae (Aranei: Araneidae), a species recently found in Far East Russia (Aranei: Linyphiidae) with notes on species grouping // Arthropoda Selecta. Vol.29. No.1. P.121-126. doi: 10.15298/arthsel. 29.1.10

РЕЗЮМЕ. Aculepeira matsudae Tanikawa, 1994, вид ранее известный из центрального Хоккайдо впервые обнаружен на Дальнем Востоке России. Ранее он указывался из Хабаровского и Приморского края как Aculepeira cf. matsudae. Вид подробно переописан, приводится дополненный диагноз, а также сравнение с двумя другими видами, обитающими на Дальнем Востоке России. Кратко обсуждается статус и принадлежность к роду Aculepeira видов, обитающих в Неотропическом царстве.

\section{Introduction}

Aculepeira Chamberlin et Ivie, 1942 is a mediumsized genus with 27 named species distributed in the Holarctic and Neotropical realms [WSC, 2020]. Seven species of this genus are known to occur in Russia [Mikhailov, 2013; WSC, 2020]. Aculepeira has the widest zonal distribution in Russia and is known from almost $73^{\circ} \mathrm{N}$ in Yakutia [Marusik et al., 1993] to the southern part of Primorskii Kray, ca $43^{\circ} 30^{\prime} \mathrm{N}$ (present data). The southernmost species in Russia was reported as Aculepeira cf. matsudae [Oliger et al., 2002; Marusik, 2009a,b]. The taxonomic status of this species was unclear because all samples were represented by females. A collection of the male allowed us to identify the species as A. matsudae Tanikawa, 1994 with certainty, a species previously known from Central Hokkaido. The goal of this paper is to provide an illustrated redescription of this species, to show variation in the shape of the epigyne, and characteristics of the ventral abdominal pattern compared to two other species known in the region.

\section{Material and methods}

Specimens were photographed with a Nikon DS-Ri2 camera attached to a Nikon SMZ25 stereomicroscope at the Far Eastern Federal University (Vladivostok), and a Canon- 


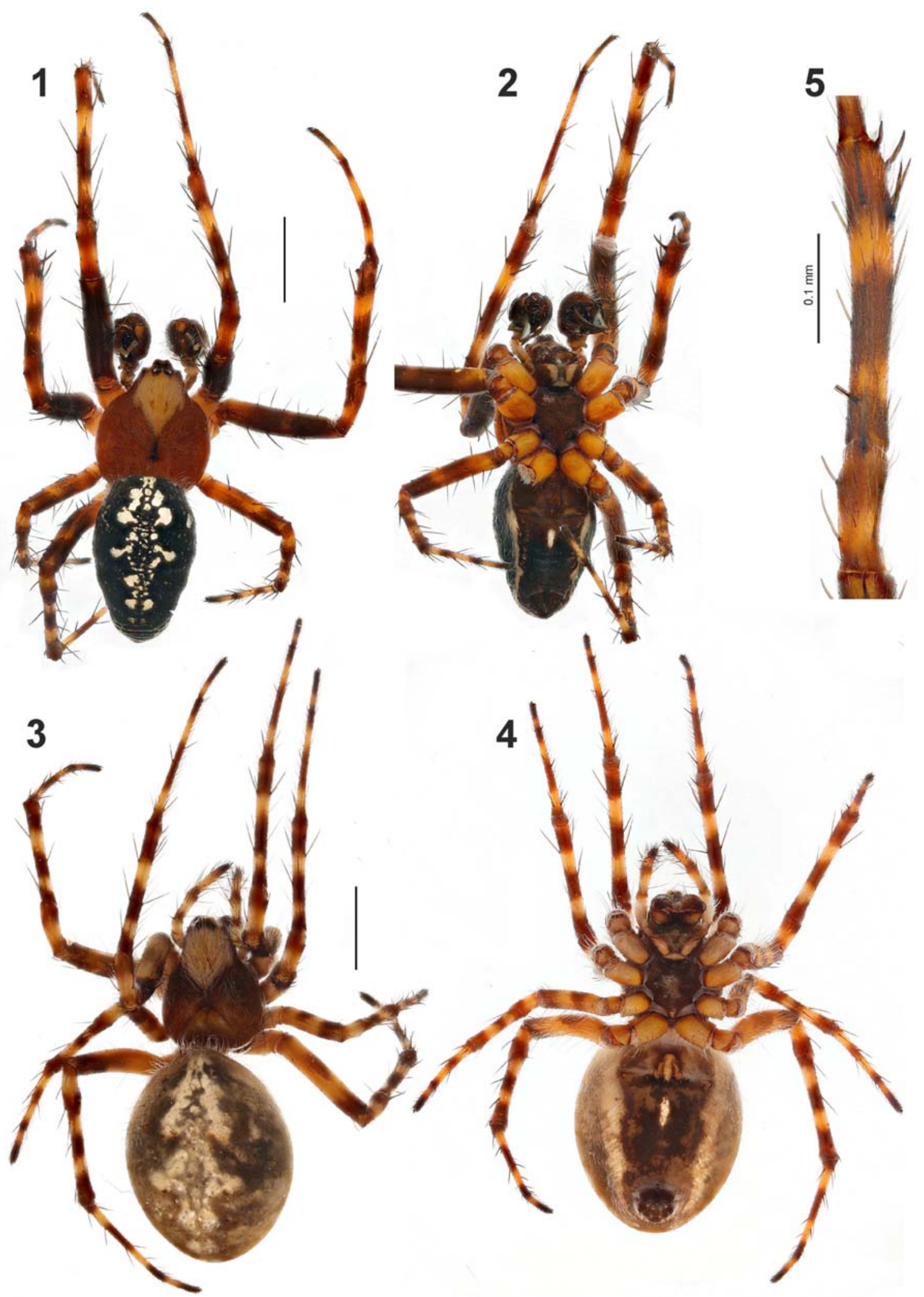

Figs 1-5. General appearance of Aculepeira matsudae. 1-2 - male, dorsal and ventral; 3-4 - female, dorsal and ventral; 5 - male's tibia II, dorsal. Scale $=2 \mathrm{~mm}$ if not otherwise indicated.

Рис. 1-5. Внешний вид Aculepeira matsudae. 1-2 - самец, сверху и снизу; 3-4 - самка, сверху и снизу; 5 - голень II самца. Масштаб 2 мм если не указано иначе. 


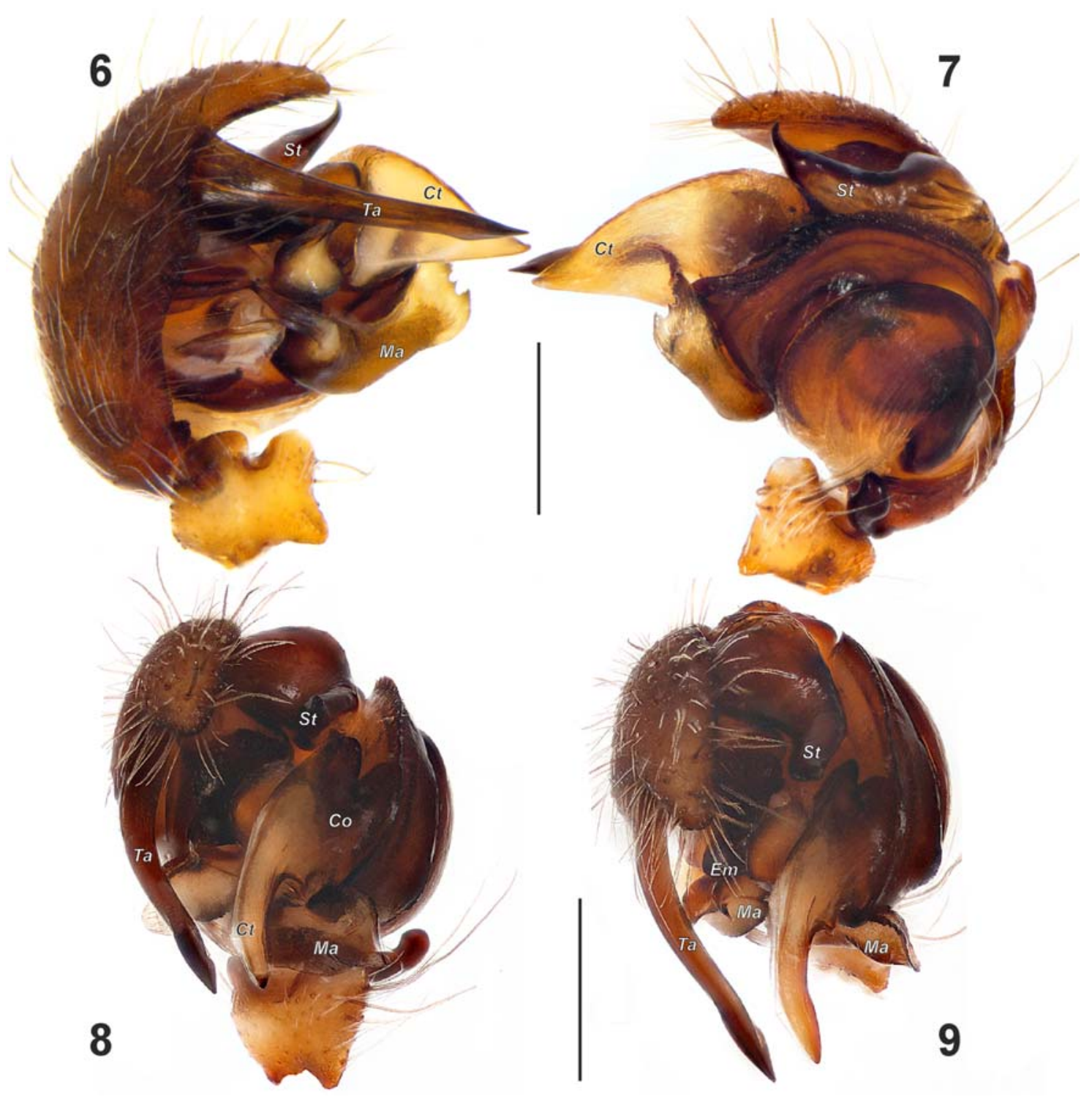

Figs 6-9. Male palp of Aculepeira matsudae. 6 - prolateral; 7 - retrolateral; 8 - ventral; 9 - anterior. Scale $=0.5 \mathrm{~mm}$. Abbreviations: $\mathrm{Co}$ - conductor, $\mathrm{Ct}$ - conductor's tip, $\mathrm{Em}$ - embolus, Ma — median apophysis, $\mathrm{St}$ — spur of the terminal apophysis, $\mathrm{Ta}$ terminal apophysis.

Рис. 6-9. Пальпа самца Aculepeira matsudae. 6 - пролатерально; 7 - ретролатерально; 8 - вентрально; 9 - спереди. Масштаб 0,5 мм. Сокращения: Со - кондуктор, $\mathrm{Ct}$ - вершина кондуктора, Em - эмболюс, Ма — срединный вырост, $\mathrm{St}-$ отросток терминального выроста, Та - терминальный вырост

7D camera on an Olympus SZX16 stereomicroscope at the University of Turku. To be photographed, the specimens were placed in dishes filled with ethanol with soft white paper at the bottom. Digital images were montaged using Zerene Stacker software (http://zerenesystems.com/cms/stacker). All measurements are in millimeters. All examined material will be deposited in the Zoological Museum of Moscow State University, Moscow, Russia.

Abbreviations used in the text and figure plates: Leg segments: $\mathrm{Fe}$ - femur, $\mathrm{Pt}$ - patella, Mt — metatarsus, $\mathrm{Ti}$ tibia, Ta - tarsus.

\section{Taxonomic survey}

\section{Aculepeira Chamberlin et Ivie, 1942}

Type species: Epeira packardii Thorell, 1875 from Labrador.

DIAGNOSIS. The genus differs from other araneid genera occurring in the Palaearctic by the presence of a white median band or longitudinal spot on the venter of abdomen (Figs 2, 4, 19, 20) (vs. median band or spot lacking or median band very wide in Larinia and related genera), terminal apophysis of the male palp with basal spur, median 

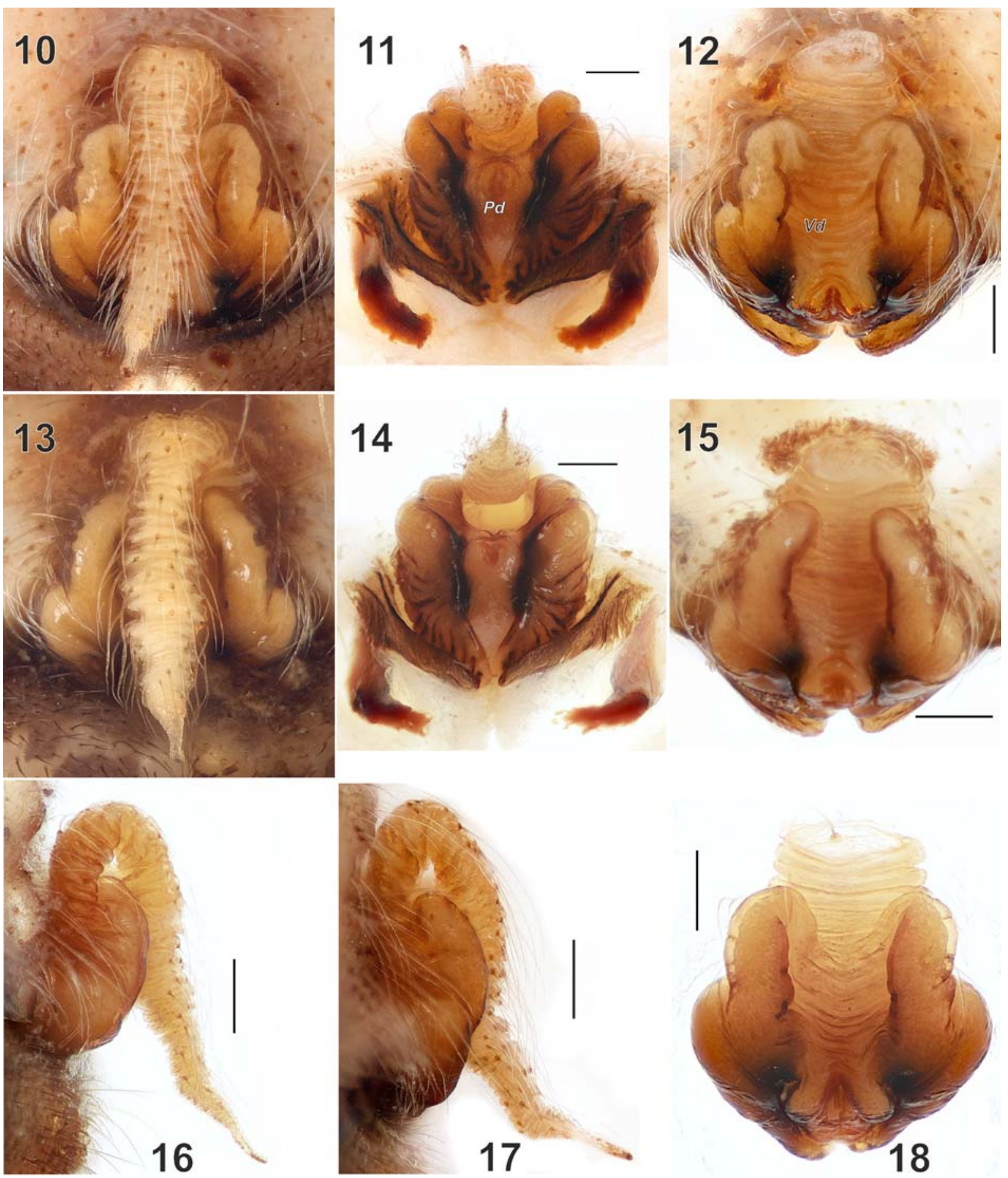

Figs 10-18. Epigyne of Aculepeira matsudae. 10, 13 - ventral; 11, 14 - posterior; 12, 15, 18 - ventral with dissected scape; 16, 17 lateral. Scale $=0.2 \mathrm{~mm}$. Abbreviations: $\mathrm{Pd}$ - posterior epigynal depression, $\mathrm{Vd}$ - ventral epigynal depression.

Рис. 10-18. Эпигина Aculepeira matsudae. 10, 13 - вентрально; 11, 14 - сзади; 12, 15, 18 - вентрально, без скапуса; 16, 17 латерально. Масштаб 0,2 мм. Сокращения: $\mathrm{Pd}$ - заднее вдавление эпигины, $\mathrm{Vd}$ - вентральное вдавление эпигины.

apophysis with a pair of thin, roundly bent prolateral processes and a lamellate retrolateral tip; epigyne with a sharply pointed tip of the scape.

COMMENTS. It seems that Neotropical species (most are known by females) are misplaced and represent a sepa- rate genus or genera. For example, Aculepeira morenoae Rubio, Izquierdo et Piacentini, 2013 from Argentina has a different habitus (elongate abdomen) and pattern, the male has an unmodified leg II, but modified femora I (bears strong ventral spines), the median apophysis has retrolateral 


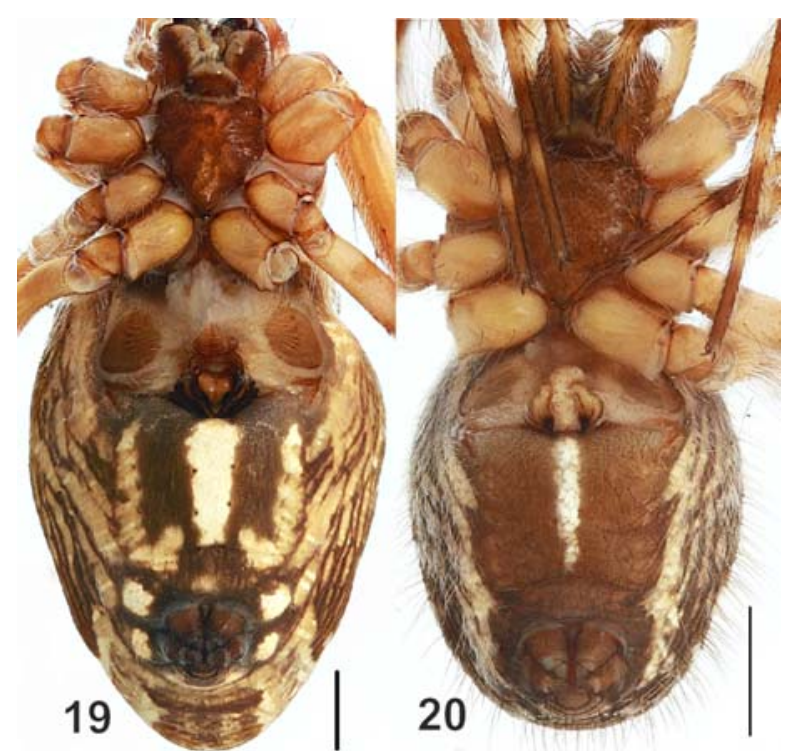

Figs 19-20. Female of Aculepeira packardi (19) and A. carbonarioides (20), ventral. Both specimens from the Kolyma River upper reaches, ca $62^{\circ} \mathrm{N}$. Scale $=1 \mathrm{~mm}$.

Рис 19-20. Самка Aculepeira packardi (19) и A. carbonarioides (20), вентрально. Оба экземпляра из верховий Колымы, примерно $62^{\circ}$ с.ш. Масштаб 1 мм.

spines which are lacking in the type species and all other species occurring in the Holarctic; the terminal apophysis is lacking a basal spur (see Rubio et al., 2013). In Holarctic Aculepeira species, the male lacks the subterminal apophysis on the palp. The pattern (lacking folium and ventral median white band or spot) and habitus (oval or elongate) in all Neotropical species are different from those of all Holarctic species.

Aculepeira matsudae Tanikawa, 199 Figs 1-18, 19.

Aculepeira matsudae Tanikawa, 1994: 180, f. 1-5 ( $\left.\sigma^{\top}+\right)$.

Aculepeira sp.: Omelko, Marusik, 2014: $313\left(\mathrm{O}^{7}\right)$.

Aculepeira cf. matsudae: Oliger et al., 2002: 93 (+); Marusik, 2009a: 96 (†); Marusik, 2009b: 381.

MATERIAL EXAMINED: RUSSIA, Khabarovskiy Kray: $1 \sigma^{7}$, Ko Mt., 1800 m., scree, $47^{\circ} 07^{\prime} \mathrm{N} 136^{\circ} 33.5^{\prime} \mathrm{E}, 17-27.06 .2013$ (M.M Omelko). Primorskiy Kray: $1 \bigcirc^{7} 1$, env. of Brovnichi Vill., $43^{\circ}$ $17^{\prime} \mathrm{N} 133^{\circ} 02^{\prime} \mathrm{E}, 300 \mathrm{~m}$, scree, 12.05 .2018 (P.S. Simonov); $1 \mathrm{O}^{\prime}$ 3 우, Bol'shoy Vorobey Mt Randge, $43^{\circ} 14^{\prime} \mathrm{N} 132^{\circ} 48^{\prime} \mathrm{E}, 1150 \mathrm{~m}$, stony slope, 21.06.2016 (P.S. Simonov); 3 क, , Livadiyskiy Mt. Range, stony slope, $43^{\circ} 04^{\prime} \mathrm{N} 132^{\circ} 46^{\prime} \mathrm{E}, 21.06 .2016$ (P.S. Simonov).

DIAGNOSIS. Aculepeira matsudae is easily differentiated from $A$. packardi (Thorell, 1875) by lacking white lateral stripes and round white spots near the spinnerets on the venter of abdomen in both sexes, as well as a short median white spot ( $v s$. stripes and round spots present, median band long, reaching spinnerets, Fig. 19). The females of $A$. matsudae differ from those of $A$. packardi by having a longer and thinner epigynal scape. Males of $A$. matsudae have a shallower depression on the conductor and a longer tip (Ct) (cf. figs 158-160 in Levi [1977]). The pattern of $A$. matsudae is more similar to A. carbonarioides (Keyserling, 1892) another species occurring in northern Far East Asia.
The males of the two species differ by tibia II: A. carbonarioides has an antero-retrolateral extension bearing a strong spine (fig. 169 in Levi [1977]), whereas in A. matsudae such an extension is lacking. Males of $A$. matsudae also have a longer tip of the conductor. Females of the two species differ by the relative length of the scape, which distinctly extends beyond the posterior margin of the epigyne in A. matsudae (Figs 10, 13, 16-17), whereas in $A$. carbonarioides the scape does not extend beyond the epigynal posterior margin. Females of $A$. carbonarioides have a longer white median band originating from the epigastral furrow ( $v s$. a short mark in the middle of the postgaster separated from the epigastral fold, cf. Figs 4 and 20).

DESCRIPTION. Male. Total length 5.75 (6.75). Carapace 3.25 (3.20) long, 2.60 (2.70) wide. Carapace dark brown, head region yellowish, covered with long, thin hairs. Chelicerae dark brown with lighter inner sides. Mouth parts and sternum dark brown. Chelicerae with 4 promarginal and 3 retromarginal teeth. Legs light brown with dark brown rings.

Abdomen dorsally blackish with a complex pattern (Fig. 3 ). Sides of abdomen blackish. Ventrally, abdomen dark gray with short median mark in the middle of the postgaster.

Male palp as in Figs 6-9; general shape like that of congeners, with a relatively stronger spur $(S t)$ of the terminal apophysis $(\mathrm{Ta})$; conductor $(\mathrm{Co})$ with very long and broad tip $(\mathrm{Ct})$ compared to other species.

Leg lengths (smaller specimen measured):

$\begin{array}{lcccccc} & \mathrm{Fe} & \mathrm{Pa} & \mathrm{Ti} & \mathrm{Mt} & \mathrm{Ta} & \text { Total } \\ \text { I } & 4.10 & 1.53 & 3.88 & 3.63 & 1.35 & 14.48 \\ \text { II } & 3.30 & 1.28 & 3.00 & 2.58 & 1.10 & 11.25 \\ \text { III } & 2.53 & 0.95 & 1.63 & 1.85 & 0.75 & 7.70 \\ \text { IV } & 3.73 & 1.20 & 2.88 & 3.25 & 1.03 & 12.08\end{array}$

Female. Total length 8.00 (10.20). Carapace 3.05 (3.40) long, 2.45 (2.70) wide. Coloration as in males, but carapace with more contrasting pattern and spots on dorsal side of abdomen larger.

Leg segment lengths (specimen 9.2 long):

$\begin{array}{lcccccc} & \mathrm{Fe} & \mathrm{Pa} & \mathrm{Ti} & \mathrm{Mt} & \mathrm{Ta} & \text { Total } \\ \text { I } & 4.30 & 1.55 & 3.80 & 3.88 & 1.43 & 14.95 \\ \text { II } & 3.80 & 1.38 & 3.25 & 3.40 & 1.25 & 13.08 \\ \text { III } & 2.78 & 1.08 & 1.78 & 2.00 & 1.05 & 8.68 \\ \text { IV } & 4.00 & 1.35 & 3.05 & 3.38 & 1.18 & 12.95\end{array}$

Epigyne as in Figs 10-18. Shape slightly variable. Scape long, more than 4 times longer than wide in ventral view; ventral sides of epigyne parallel or convergent anteriorly (in specimens from Russia; in the paratype female from Japan the sides are divergent). Ventral $(V d)$ and posterior $(P d)$ epigynal depression more than 2 times longer than wide.

NATURAL HISTORY. All specimens from Russia have been collected on scree or in heaths of Microbiota in mountain tundra [Simonov, 2019]. The spiders make webs usually between stones, like the similar species $A$. carbonarioides.

DISTRIBUTION. This species is restricted to Far East Asia and known from distant localities: the southern part of Khabarovskiy Kray, the southern part of Primorskiy Kray (from 3 localities near each other), and in Central Hokkaido (from 5 localities near each other: Mt. Higashi-NupukaushiNupuri: $43.252221^{\circ} \mathrm{N}, 143.099002^{\circ} \mathrm{E}$, the type locality; Mt. Nishi-Nupukaushi-nupuri: $43.254708^{\circ} \mathrm{N} 143.080609^{\circ} \mathrm{E}$; Mt. Haku-unzan, $43.258776^{\circ} \mathrm{N}, 143.115281^{\circ} \mathrm{E}$ and Mt. Ganseki, $43.255221^{\circ} \mathrm{N}, 143.117566^{\circ} \mathrm{E}$, Mt. Yuni-Ishikari-dake, $43.564451^{\circ} \mathrm{N} 143.070314^{\circ} \mathrm{E}$. 


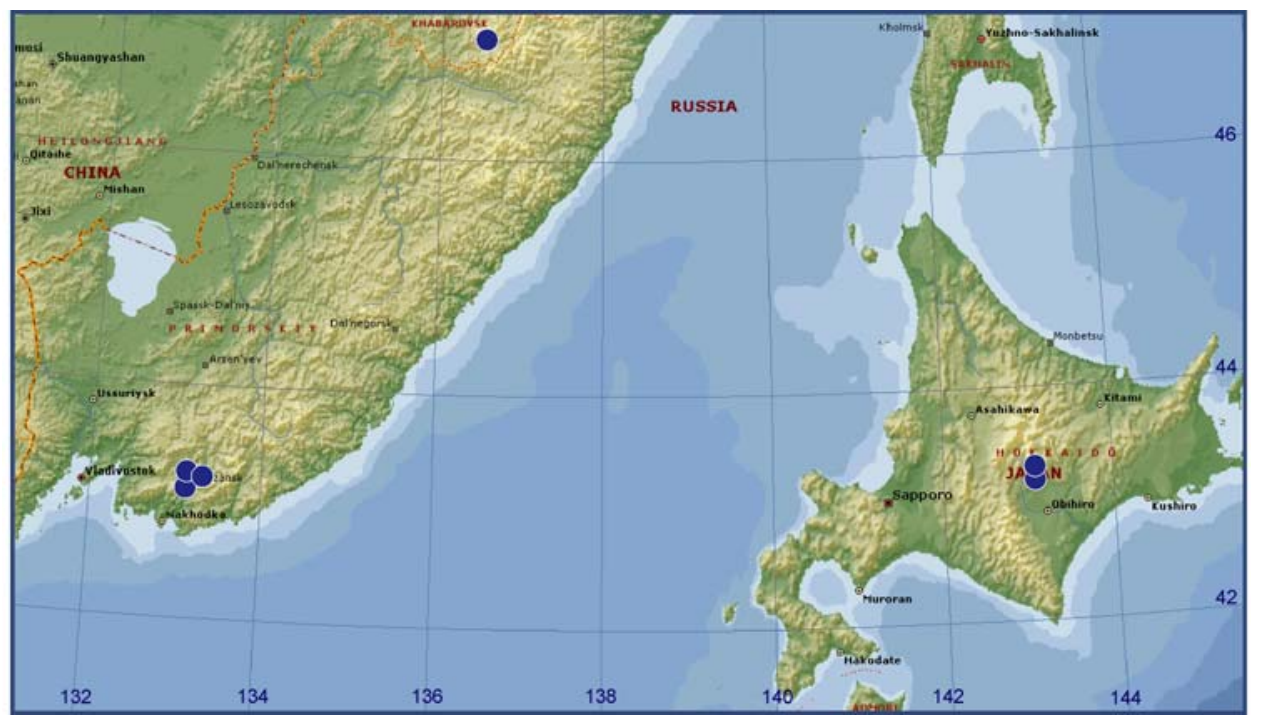

Fig. 21. Distribution records of Aculepeira matsudae.

Рис. 21. Известные точки находок Aculepeira matsudae.

Acknowledgments. We thank Kirill A. Vinnikov head of Laboratory of ecology and evolutionary biology of aquatic organisms (LEEBAO, Vladivostok, Russia) and Ilari Sääksjärvi (Zoological Museum, University of Turku, Finland) for permission to use the lab facilities. Ms. Mayumi Matsuda (Hokkaido, Japan) and Akio Tanikawa (Tokyo, Japan) kindly provided data about the distribution of A. matsudae in Hokkaido. The English of the final draft was kindly checked and corrected by Sarah Crews (San Francisco, USA)

\section{References}

Levi H.W. 1977. The orb-weaver genera Metepeira, Kaira and Aculepeira in America north of Mexico (Araneae, Araneidae) // Bulletin of the Museum of Comparative Zoology. Vol.148. No.3. P.185-238.

Marusik Yu.M., Eskov K.Y., Koponen S., Vinokurov N.N. 1993. A check-list of the spiders (Aranei) of Yakutia, Siberia // Arthropoda Selecta. Vol.2. No.2. P.63-79.

Marusik Yu.M. 2009a. A check-list of spiders (Aranei) from the Lazo Reserve, Maritime Province, Russia // Arthropoda Selecta. Vol.18. No.1-2. P.95-109.

Marusik Yu.M. 2009b. [Order Aranei - Spiders] // Nasekomye Lazovskogo zapovednika. Vladivostok: Dal'nauka. P.380-392 [in Russian].
Mikhailov K.G. 2013. The spiders (Arachnida: Aranei) of Russia and adjacent countries: a non-annotated checklist // Arthropoda Selecta. Supplement. No.3. P.1-262.

Oliger T.I., Marusik Yu.M., Koponen S. 2002. New and interesting records of spiders (Araneae) from the Maritime Province of Russia // Acta Arachnologica. Vol.51. No.2. P.93-98.

Omelko M.M., Marusik Yu.M. 2014. New data on spiders (Aranei) from southern part of the Khabarovsk Province // Arthropoda Selecta. Vol.23. No.3. P.311-318.

Rubio G.D., Izquierdo M.A., Piacentini L.N. 2013. A new orbweaving spider from the Argentinean flooding pampas grasses: Aculepeira morenoae new species (Araneae, Araneidae) // Zootaxa. Vol.3613. No.6. P.548-556.

Simonov P.S. 2019. [Spatial distribution of the orb-weaving spiders (Aranei: Araneidae) in the upper part of the Livadiisky Mt. Range (Southern Primorie)] // Chteniya pamyati A.I. Kurentsova. No.30. P.183-190 [in Russian].

Tanikawa A. 1994. A new species of the spider genus Aculepeira (Araneae: Araneidae) from Japan // Acta Arachnologica. Vol.43. No.2. P.179-182.

WSC. 2020. World Spider Catalog. Version 21.0. Natural History Museum Bern, online at http://wsc.nmbe.ch, accessed on 9th of February, 2020.

Responsible editor K.G. Mikhailov 